\title{
Floral sources to Tetragonisca angustula (Hymenoptera: Apidae) and their pollen morphology in a Southeastern Brazilian Atlantic Forest
}

\author{
Juliana Almeida Braga ${ }^{1}$, Érika Oliveira Sales ${ }^{2}$, João Soares Neto ${ }^{1}$, Marilena Menezes Conde ${ }^{3}$, \\ Ortrud Monika Barth ${ }^{4} \&$ Maria Cristina Lorenzon ${ }^{1}$ \\ 1. Instituto de Zootecnia, Universidade Federal Rural do Rio de Janeiro, BR 465, km 07, CEP 24800-000, Seropédica, \\ RJ, Brasil; jualmeidabraga@yahoo.com.br, josoares@ufrrj.br, lorenzon_ufrrj@yahoo.com.br \\ 2. Laboratório de Palinologia, Departamento de Botânica, Instituto de Biologia, Universidade Federal do Rio de Janeiro, \\ Rio de Janeiro, RJ, Brasil; erika_melisso@yahoo.com.br \\ 3. Departamento de Botânica, Instituto de Biologia, Universidade Federal Rural do Rio de Janeiro, BR 465, km 07, CEP \\ 24800-000, Seropédica, RJ, Brasil; lenaconde@yahoo.com.br \\ 4. Instituto Oswaldo Cruz, Departamento de Virologia, Av. Brasil, 4365, CEP 21045-900, Rio de Janeiro, RJ, Brasil; \\ barth@ioc.fiocruz.br
}

Received 31-VIII-2011. Corrected 10-V-2012. Accepted 11-VI-2012.

\begin{abstract}
The stingless bees are important flowers visitors of several plant species, due to their feeding habits and foraging behavior, constituting an important group to maintain biodiversity and the dynamics of tropical communities. Among stingless bees, Tetragonisca angustula is widely distributed in tropical habitats, and has been considered an important pollinator of different plant families. To support a rational economic use of this group, there is a need to characterize the plant species that represent important sources as part of their diet, as preferred, alternative or casual food sources. The aim of this survey was to distinguish the plant species that T. angustula visited most often. The study was undertaken in four regions of the Atlantic Rainforest in Rio de Janeiro state (Brazil) over a year from March 2008 to February 2009. For this, we collected bees, flowering plants and bee pollen loads from the four sites, and evaluated pollen morphology in the laboratory. Field observations showed the presence of plants belonging to ten different families and pollen loads showed the presence of pollen types belonging to 26 plant families. There were strong differences between pollen types, especially regarding pollen grain shape. The present survey suggests a high value of these plant species as trophic resources for the T. angustula in the understory of Atlantic Rainforest. Changes in these fragments of this forest may compromise the availability of resources for Tetragonisca angustula species and other stingless bees. Rev. Biol. Trop. 60 (4): 1491-1501. Epub 2012 December 01.
\end{abstract}

Key words: stingless bees, pollen morphology, trophic niche, Meliponina, tropical forest.

In tropical ecosystems, wild bees play an important role in maintaining animal and plant communities. According to Kerr et al. (2001), $30-80 \%$ of plants are pollinated by one or more species of stingless bees (Meliponina) in their biomes. The survival of these bee species depends on one of the largest biomes at risk, the Atlantic Rainforest, which has one of the highest biodiversities on the planet. This ecosystem suffers from strong fragmentation and degradation due to human occupation, for crop and livestock production, and has maintained only $8 \%$ of its original area (Fundação SOS Mata Atlântica \& INPE 2009).

Among stingless bees, Tetragonisca angustula Latreille (Apidae: Meliponina), is widely distributed and nests in varying substrates, becoming also abundant in disturbed areas. They are generalists in their habits and their efficient pollination on the tropical flora is remarkable. T. angustula is a gentle species, and easily adjusts to beekeeping used to collect 
honey or to pollinate crops (Kleinert \& Fonseca 1995, Malagodi-Braga \& Kleinert 2004). It is essential to know which bee plants are attractive to this species in their natural habitats, in order to allow its protection and maintenance in natural environments.

The identification of plants visited by forager bees can be done by direct observation in the field, and by observing and counting the bees in the flowers. Collecting pollen from beehives is also used to verify the botanical origin of pollen loads (Louveaux et al. 1970). These two methods can highlight the sources that stand out in the bee diet. They also provide information to help the stingless bees keeper to organize a floral calendar and field tasks to better manage their beehives for sustainable use.

The purpose of this study was to use two different methods to identify the plant species visited most frequently by $T$. angustula in tropical vegetation from four Brazilian Atlantic areas, describing their pollen morphologies, and to note the occurrence of these attractive plants.

\section{MATERIAL AND METHODS}

The study was carried out in four regions located in Rio de Janeiro state, Bra-

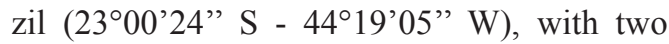
study sites in each region. Two regions were on the islands (Ilha Grande and Itacuruça) and the other two in the mainland (Ariro and Tinguá). Among the four regions only one (Ilha Grande), as an insular region, belongs to an environmental protection unit. This choice was strategic as it is a high population of T. angustula has been reported before (Lorenzon et al. 2006), a condition which was not known for the other regions. All the studied regions lie in the Atlantic Rainforest morphoclimatic domain (Ab’Sáber 1977) and largely with a closed canopy forest (Dense Ombrophilous Forest), a secondary growth forest, greenlands, mangrove, salt marsh and beach vegetation. The canopy is high, ranging from $30-40 \mathrm{~m}$ in height. In the regions there are also some patches of disturbed vegetation due to human activities.
In the studied sites, there are some parts dominated by herbaceous plants, medium size shrubs and large tree species, other parts the Atlantic Rainforest is dense and bright in the lowland, montane and mangrove vegetation. In the island's trails, there is also the presence of rocky outcrops with herbaceous vegetation and mangroves. Particularly in the mainland's trails there are some rural residential area with houses and small farmers, they are strongly occupied by abandoned pastures; comparing these with the insular sites the last one seems more protected. In general, the regions are dominated by an historic impact from human activities, such as fire, garbage, especially due to the presence of the tourists, and the invasion of banana culture (Musa spp.), as occurs in Itacuruça island (Table 1).

This article deals with the flora visited by Tetragonisca angustula from an in-situ sampling of flowers observation or insects capture and from pollen loads analyses. Sampling started in March 2008 and finished in February 2009. For observation and captures in the flowers, bimonthly sampling was done in four sites chosen at random, one in each region, six hours per day (6:00 to $12: 00 \mathrm{~h}$, period of highest visitation of bees in the forest, totalizing a schedule 30 hours per site); evaluated areas included trails and dirty roads on the edge of the forest, human disturbed ones and others with well-developed forest. Sampling was done at each site within a delimited restricted area of about $8-10 \mathrm{~m}$ from the forest edges and over $400 \mathrm{~m}$ of length, and this same area was analyzed each sampling day. Most of the observed vegetation was confined to the understory, or subcanopy, which was composed of climbers, herbaceous and shrubs plants, while trees were difficult to access, because the canopy is very high and dense.

With the use of insect nets, T. angustula was captured when observed in flowering plants, considering the overall abundance as much as possible. We avoid the prolonged presence at a flower patch for more than $10 \mathrm{~min}$. Plant species were considered attractive to bees when they were visited by more than five bees 
TABLE 1

Sampling sites, their characterization and plant species. Rio de Janeiro state, Brazil, 2009

\begin{tabular}{|c|c|c|}
\hline Studied region & Characteristics & Plant species observed* \\
\hline Ilha Grande & $\begin{array}{l}\text { Most representative studied site, } \\
\text { it is the most covered by Atlantic } \\
\text { Rainforest }\end{array}$ & $\begin{array}{l}\text { Baccharis dracunculifolia DC; Baccharis trinervis (Lam.) } \\
\text { Persoon, Bidens pilosa L., Erechtites valerianaefolia DC., and } \\
\text { Wedelia paludosa DC. (Asteraceae); Adenocalyma dusenii } \\
\text { Kraenzlin (Bignoniaceae); Hyptis lophanta Mart. Ex. Benth } \\
\text { (Labiatae); Heteropteris acceroides Gr. (Malpighiaceae); } \\
\text { Tibouchina granulosa Cogn. (Melastomataceae); Rubus rosifolius } \\
\text { Sm. (Rosaceae); Trema micantra (L.) (Ulmaceae); Stachytarpheta } \\
\text { cayennensis (Rich.) Vahl. (Verbenaceae) }\end{array}$ \\
\hline Itacuruça & $\begin{array}{l}\text { Studied site providing greater } \\
\text { vegetation cover, although the } \\
\text { presence of agriculture }\end{array}$ & $\begin{array}{l}\text { Vernonia maximillian Lam. (Asteraceae); Euphorbia heterophylla } \\
\text { L. (Euphorbiaceae); Leonurus sibiricus L. (Lamiaceae) }\end{array}$ \\
\hline Ariró & $\begin{array}{l}\text { Among the studied sites this is the } \\
\text { most devastated, regarding to the } \\
\text { agriculture occupation }\end{array}$ & $\begin{array}{l}\text { Elephantopus scaber L. (Asteraceae); Croton lundianus (Diedr.) } \\
\text { Mull.Arg. (Euphorbiaceae); Ludwigia suffruticosa (L.) Hara } \\
\text { (Onagraceae). }\end{array}$ \\
\hline Tinguá & $\begin{array}{l}\text { Studied site with significant area } \\
\text { covered by Atlantic Rainforest, } \\
\text { although the strong presence of } \\
\text { human community }\end{array}$ & $\begin{array}{l}\text { Tabebuia alba (Chamiso) Sandwith (Bignoniaceae); Ipomoea } \\
\text { purpurea (L.) Roth. (Convolvulaceae); Croton lundianus (Diedr.) } \\
\text { Mull.Arg. (Euphorbiaceae); Mimosa bimucronata (DC.) Kuntze } \\
\text { (Fabaceae); Urena lobata Lineu. (Malvaceae); Psydium guajava } \\
\text { L. and Syzygium cumini (L.) Skeels. (Myrtaceae). }\end{array}$ \\
\hline
\end{tabular}

*These plants were observed in the studied regions, but not necessarily were observed being visited by T. angustula.

during a particular time interval (10min). To reach the subcanopy, nets were attached to long poles of about seven meters height. The plants were prepared as vouchers and identified with the help of specialized literature, other collections and scientists at Universities. The vouchers prepared were included in the collection of RBR herbarium at the Universidade Federal Rural do Rio de Janeiro.

The other method to identify the plants visited by $T$. angustula was to collect the pollen loads and honey. Over the year, pollen loads were collected in five T. angustula hives belonging to a beekeeper located in one of the studied regions (Ilha Grande) (Fig. 1); the other regions did not have this activity. Every time five bees entered the hive, they were captured to remove their pollen loads. A total of 60 samples were obtained during the study. During the honey flow, samples of $10 \mathrm{~g}$ were collected directly from the pots with a syringe.

Pollen and honey analysis were carried out using the direct methodology (Louveaux et al.
1970) and acetolysis (Erdtman 1960). Qualitative analysis of pollen grains allowed the determination of botanical species that make up the pollen spectrum. Through quantitative analysis of the pollen grains, it was possible to establish the amount of pollen supplied by each floral species, and the frequency when compared with other plants of their diet. Photomicrographs of pollen grains were also obtained and catalogued. Data from literature (Barth 1989) and the reference pollen slide collection of the Laboratory of Palynology (Institute of Biology, Universidade Federal do Rio de Janeiro) were used in the pollen identification. Plant classification is in accordance with the Angiosperm Phylogeny Group (2003). The polar axis (P) and equatorial diameter $(\mathrm{E})$ of 25 pollen grains were measured; other measurements, such as the apertures, endoapertures and thickness of the exine, were taken in for 10 pollen grains. Measurements were used to define shape and size classes of pollen, according to definitions of Barth \& Melhem (1988). To calculate the 

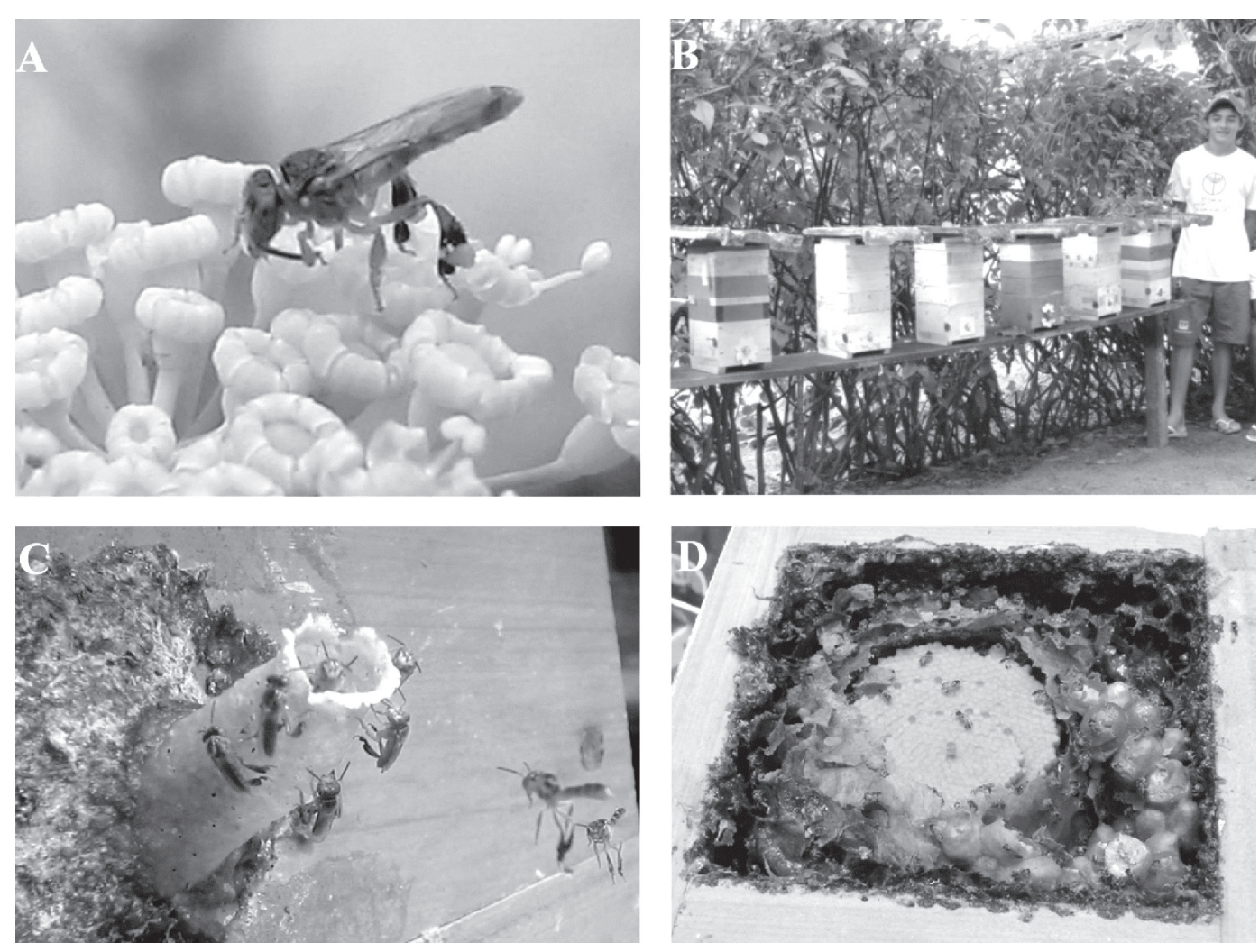

Fig. 1. (A) Tetragonisca angustula foraging in flowers. (B) A meliponary. (C) The hive entrance. (D) Inside the nest.

mean of each parameter, we used the arithmetic mean with the standard deviation method. The ratio of polar to equatorial axis $(\mathrm{P} / \mathrm{E})$ based on the mean, was used for characterization of pollen grains shape.

\section{RESULTS}

From floral observations in the understory, we found that $T$. angustula visited 61 plant species, 45 of which had low visitation levels; $81 \%$ were found in Ilha Grande (island), $6 \%$ in the other island (Itacuruça) and $13 \%$ in the two mainland regions (Ariró and Tinguá). Changes in these fragments of the Atlantic Rainforest has an influence on T. angustula abundance, as well as these bees as pollinators influence the natural areas botanical composition provided by them.
The smaller number of bees in some regions may be an indicative of the negative impacts present in these natural environments, which can lead to changes in the bees' community and plants. This result reinforce that $T$. angustula bees are dependent from the flora of the Atlantic tropical forest, although this bee species may be considered the most resistant to adverse conditions.

Visitation in Asteraceae and Anacardiaceae were the best represented plant families (three species each). Solanaceae and Fabaceae were represented by two plant species, and Acanthaceae, Sapindaceae, Myrsinaceae, Commelinaceae, Myrtaceae and Rhamnaceae were represented by one species each (Table 2).

Of the plant species mentioned in the present study, Schinus terebinthifolius Raddi L. (Anacardiaceae) is the most popular plant 
TABLE 2

Plant species visited by T. angustula (\%) in four sites located in Atlantic Rainforest: Ilha Grande, Itacuruça, Ariró and Tinguá. Rio de Janeiro state, Brazil, 2009

\begin{tabular}{|c|c|c|c|c|}
\hline \multirow{2}{*}{ Plant species visited by $T$. angustula } & \multicolumn{4}{|c|}{ Studied regions and frequency $(\%)$} \\
\hline & Ilha Grande & Itacuruça & Ariró & Tinguá \\
\hline \multicolumn{5}{|l|}{ Anacardiaceae } \\
\hline Schinus terebinthifolius Raddi & 21 & & & \\
\hline \multicolumn{5}{|l|}{ Acanthaceae } \\
\hline Ruellia silvaecola Lindau & & & 3 & \\
\hline \multicolumn{5}{|l|}{ Anacardiaceae } \\
\hline Mangifera indica $\mathrm{L}$. & 6 & & & \\
\hline Tapirira guianensis Aubl. & 6 & & & \\
\hline \multicolumn{5}{|l|}{ Asteraceae } \\
\hline Albertina brasiliensis Spreng. & 12 & & & \\
\hline Baccharis dracunculifolia DC. & 6 & & & \\
\hline Wedelia paludosa DC. & & & & 3 \\
\hline \multicolumn{5}{|l|}{ Commelinaceae } \\
\hline Tradescantia zebrina Hort. Ex Loud. & & 6 & & \\
\hline \multicolumn{5}{|l|}{ Fabaceae } \\
\hline Inga edulis Mart. & 6 & & & \\
\hline Schizolobium parahyba (Vell.) Blake & 6 & & & \\
\hline \multicolumn{5}{|l|}{ Myrsinaceae } \\
\hline Myrsine coriacea (Sw.) R. Br. & 3 & & & \\
\hline \multicolumn{5}{|l|}{ Myrtaceae } \\
\hline Psidium guajava $\mathrm{L}$. & 3 & & & \\
\hline \multicolumn{5}{|l|}{ Rhamnaceae } \\
\hline Reissekia smilacina (Sm.) Steud. & & & & 7 \\
\hline \multicolumn{5}{|l|}{ Sapindaceae } \\
\hline Allophylus petiolulatus Radlk & 6 & & & \\
\hline \multicolumn{5}{|l|}{ Solanaceae } \\
\hline Solanum aculeatissimum Jacq. & 3 & & & \\
\hline Solanum asperolanatum Ruiz \& Pav. & 3 & & & \\
\hline Total & 81 & 6 & 3 & 10 \\
\hline
\end{tabular}

and important food sources for T. angustula. It has the greatest flower density and provides easy access to the bees. Other plants were also visited occasionally: Albertina brasiliensis Spreng. (Asteraceae), Allophylus petiolulatus Radlk. (Sapindaceae), Baccharis dracunculifolia DC. (Asteraceae), Inga edulis Mart. (Fabaceae-Mimosoideae), Mangifera indica L., Reissekia smilacina (Sm.) Steud. (Rhamnaceae), Schizolobium parahyba (Vell.) Blake (Fabaceae), Tapirira guianensis Aubl. (Anacardiaceae), Tradescantia zebrina Hort. (Commelinaceae). Myrsine coriacea (Sw.) R. Br. (Myrsinaceae), Psidium guajava L.
(Myrtaceae), Ruellia silvaecola Lindau (Acanthaceae), Solanum aculeatissimum Jacq. (Solanaceae), Solanum asperolanatum Ruiz \& Pav. (Solanaceae) and Wedelia paludosa DC. (Asteraceae). Illustrations of some of these plant species are presented in figure 2.

The pollen loads collected in the insular region (Ilha Grande) showed the presence of 39 pollen types belonging to 28 plant families. A total of 67934 grains of pollen were found.

The rudimentary data on Brazilian Atlantic Rainforest bee flora and the lack of greater knowledge of the reference pollen cause great difficulties in analyzing the 

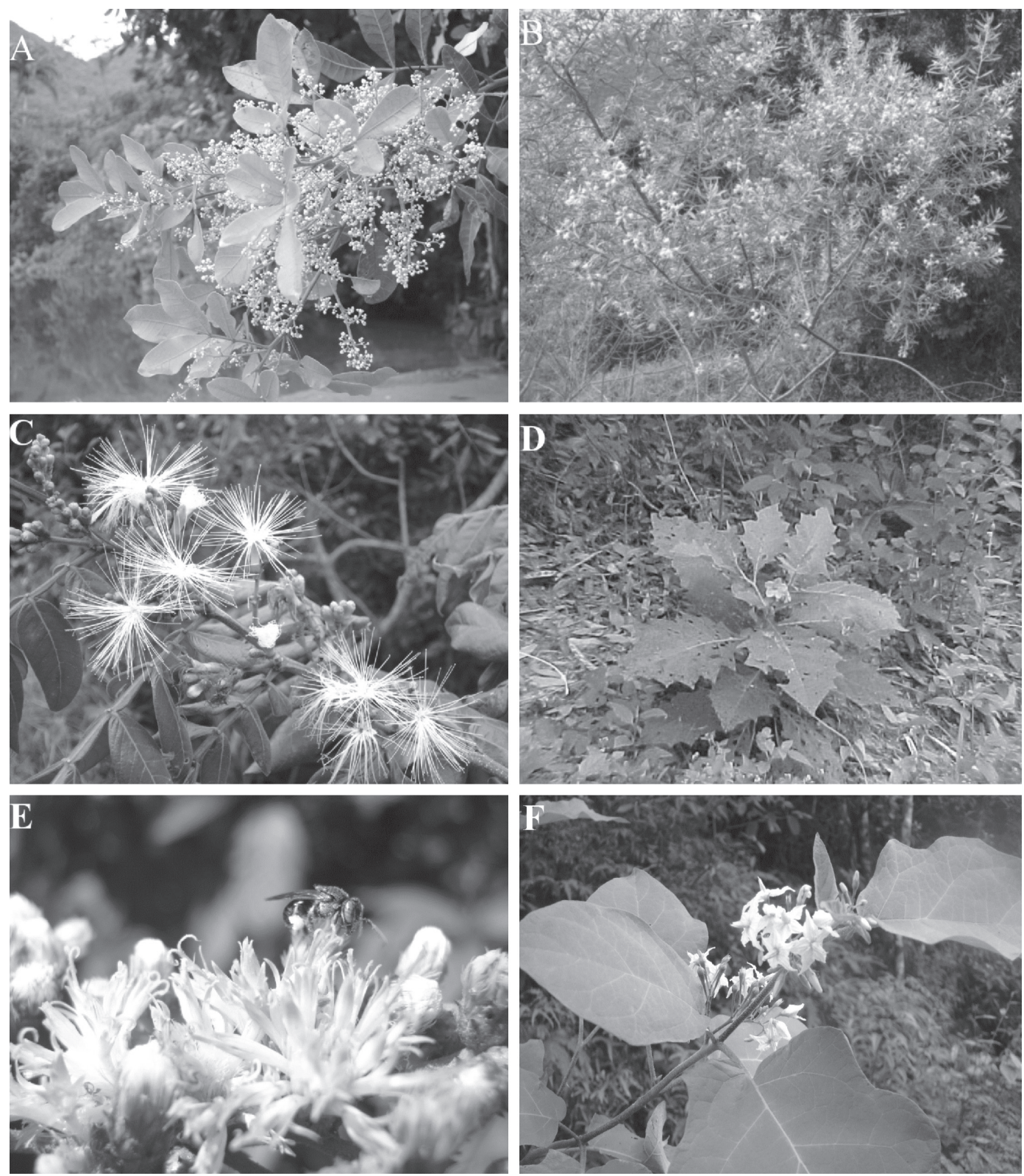

Fig. 2. (A) Schinus terebinthifolius. (B) Baccharis dracunculifolia. (C) Inga edulis. (D) Solanum aculeatissimum. (E) Albertina brasiliensis. (F) Solanum asperolanatum.

pollen loads, and in the identification of the botanical species sought by bees. Meliaceae and Ulmaceae (Trema micrantha) were the most frequently seen. Additional taxa identified from bee pollen loads were Amaranthaceae (Amaranthus and Gomphrena pollen types),
Anacardiaceae (Tapirira), Annonaceae (Araticum), Arecaceae (Cocos lucifera), Asteraceae (Piptocarpha), Bignoniaceae (Mansoa), Brassicaceae, Cactaceae, Caesalpiniaceae, Cecropiaceae (Cecropia), Chenopodiaceae, Cyperaceae, Euphorbiaceae (Alchornea, Dalechampia and 
Sapium), Fabaceae (Anadenanthera, Canavalia and Mimosa caesalpiniaefolia), Loranthaceae (Struthanthus), Malpighiaceae (Tetrapterys), Malvaceae, Melastomataceae, Myrtaceae (Eucalyptus and Myrcia), Piperaceae (Piper), Poaceae, Polygonaceae, Solanaceae (Cestrum), Symplocaceae, Ulmaceae (Celtis) and Verbenaceae (Aegiphila). The number of pollen grains presented in the bee loads sampled varied between 4 000-9 000, monthly, and they were well distributed throughout the year (Table 3). Palinology method provides more information on the diet of $T$. angustula, indicating new plant families (as Meliaceae).
In our study, the intense honey flow occurs from November to March. The honey samples showed the presence of pollen types from Tapirira (Anacardiaceae), Anadenanthera (Mimosaceae) and several species of Meliaceae. Strong morphological differences can bee seen among the pollen types, mainly with regard to their size, aperture and surface features (Fig. 3). A description on the morphology of the common pollen types is presented:

- Albertina brasiliensis Spreng. (Asteraceae). Pollen grains are monads, apolar, medium size, radiosymmetrical,

TABLE 3

Plant families, pollen types and frequency (\%) of T. angustula in the insular site (Ilha Grande). Rio de Janeiro state, Brazil, 2009

\begin{tabular}{|c|c|c|c|}
\hline Plant families and Pollen types & Frequency & Plant families and Pollen types & Frequency \\
\hline Amaranthaceae & & Indeterminate & 0.001 \\
\hline Amaranthus & 0.01 & Loranthaceae & \\
\hline Gomphrena & 0.6 & Struthanthus & 0.3 \\
\hline Anacardiaceae & & Type 1 & 0.03 \\
\hline Tapirira & 5.3 & Malpighiaceae & \\
\hline Annonaceae & & Tetrapterys & 2.3 \\
\hline Araticum & 0.01 & Type 1 & 0.2 \\
\hline Arecaceae & & Malvaceae & \\
\hline Cocos lucifera & 0.03 & Hibiscus & 0.001 \\
\hline Asteraceae & & Type 1 & 0.003 \\
\hline Type 1 & 0.2 & Melastomataceae & 4 \\
\hline Piptocarpha & 14.1 & Meliaceae & 43.6 \\
\hline Bignoniaceae & & Myrtaceae & \\
\hline Mansoa & 0.3 & Eucalyptus & 1.8 \\
\hline Brassicaceae & 0.07 & Myrcia & 0.02 \\
\hline Cactaceae & 0.03 & Piperaceae & \\
\hline Caesalpiniaceae & 2 & Piper & 6.3 \\
\hline Cecropiaceae & & Poaceae & 1.9 \\
\hline Cecropia & 0.09 & Polygonaceae & 0.09 \\
\hline Chenopodiaceae & 0.7 & Solanaceae & \\
\hline Cyperaceae & 0.5 & Cestrum & 5.5 \\
\hline Euphorbiaceae & & Symplocaceae & 1.8 \\
\hline Alchornea & 0.6 & Ulmaceae & \\
\hline Dalechampia & 0.01 & Trema micrantha & 4.8 \\
\hline Sapium & 0.1 & Celtis & 0.04 \\
\hline Fabaceae & & Verbenaceae & \\
\hline Anadenanthera & 2.4 & Aegiphila & 0.05 \\
\hline Canavalia & 0.3 & & \\
\hline Mimosa caesalpiniaefolia & 0.1 & & \\
\hline
\end{tabular}



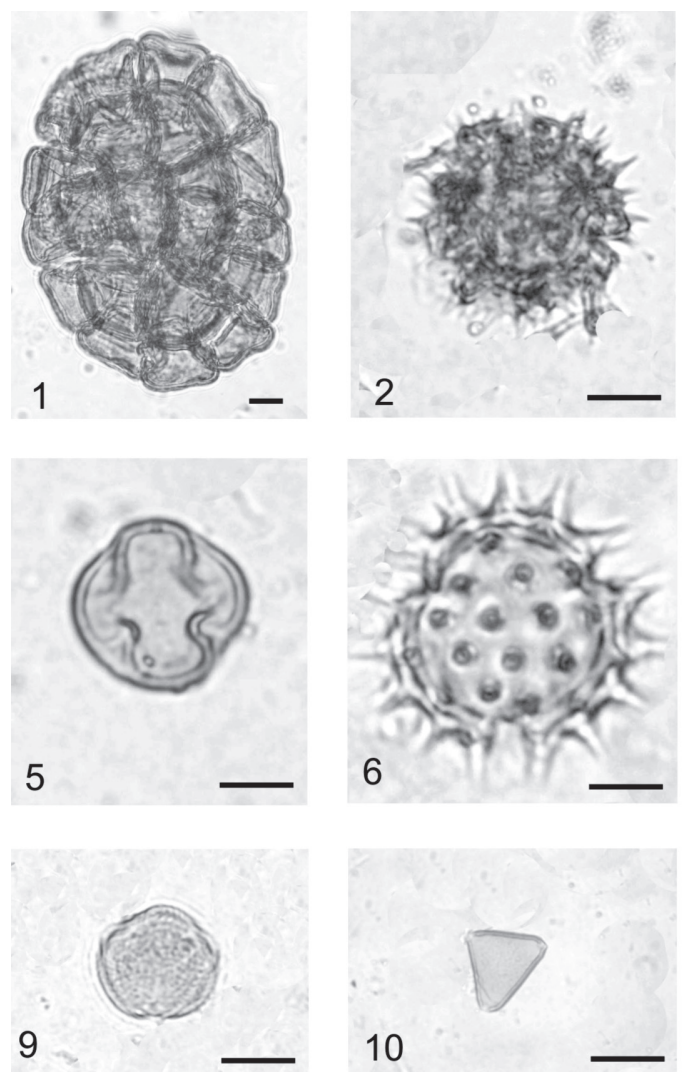
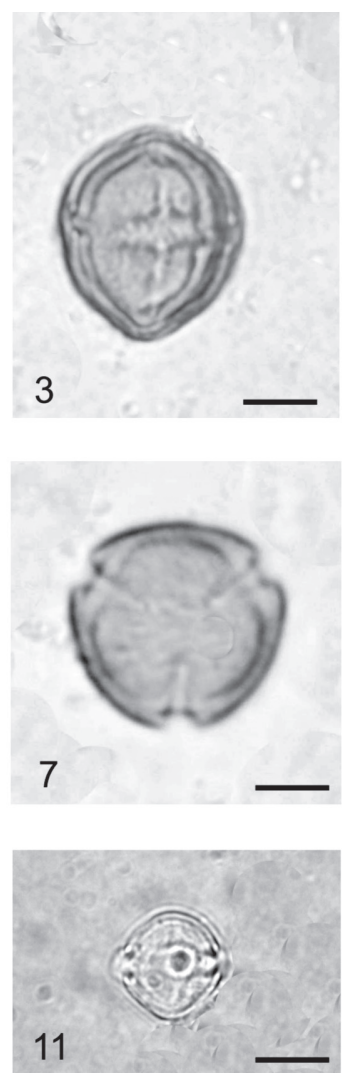
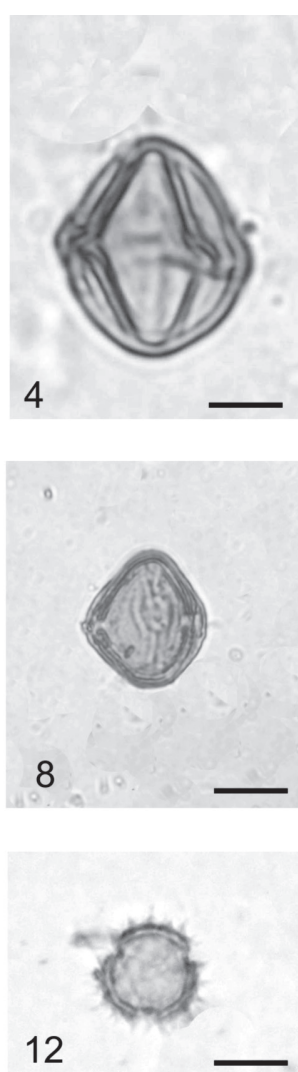

Fig. 3. Examples of pollen morphology. 1-Inga edulis (400x). 2-Albertina brasiliensis (1000x). 3-Schinus terebinthifolius (1000x). 4-Solanum asperolanatum (1000x). 5-Myrsine coriacea (1000x), 6-Wedelia paludosa (1000x). 7-Tapirira guianensis (100x). 8-Reisseckia smilacina (1000x). 9-Schizolobium parahyba (100x). 10-Allophylus petiolulatus (1000x). 11-Solanum aculeatissimum (1000x). 12-Baccharis dracunculifolia (1000x).

spheroidal, ambit rounded, 3-colporate, and have surfaces with spines $4.2 \mu \mathrm{m}$ high and an exine $2.7 \mu \mathrm{m}$ thick.

- Allophylus petiolulatus Radlk (Sapindaceae). Pollen grains are monads, isopolar, small size, radiosymmetrical, ambit triangular with rounded corners, 3-porate, with a microreticulate surface and an exine $1.7 \mu \mathrm{m}$ thick.

- Baccharis dracunculifolia DC. (Asteraceae). Pollen grains are monads, isopolar, radiosymmetrical, small size, ambit subcircular to circular, 3-colporate, and have surfaces with conical spines $2.0 \mu \mathrm{m}$ high and an exine $1.4 \mu \mathrm{m}$ thick.

- Inga edulis Mart. (Fabaceae-Mimosoideae). Pollen grains are assembled in polyads of very large size. Each pollen grains of a small size, with a psilate surface and an exine $1.7 \mu \mathrm{m}$ thick.

- Myrsine coriacea (Sw.) R. Br. (Myrsinaceae). Pollen grains are monads, isopolar, small size, radiosymmetrical, prolate spheroidal form, and 3-colpate, with a psilate surface and an exine $2.2 \mu \mathrm{m}$ thick. Measurements: $\mathrm{P}=20.8 \mu \mathrm{m}(19.3-22.3 \mu \mathrm{m})$; $\mathrm{E}=20.4 \mu \mathrm{m}(18.6-22.2 \mu \mathrm{m}) ; \mathrm{P} / \mathrm{E}=1.02$.

- Reissekia smilacina (Sm.) Steud. (Rhamnaceae). Pollen grains are monads, isopolar, radiosymmetrical, medium size, sub-prolate, ambit sub-rounded, 3-colporate, endoapertures lalongates, with a microreticulate surface and an exine $1.7 \mu \mathrm{m}$ thick. Measurements: $\mathrm{P}=34.1 \mu \mathrm{m}$ 
(31.5-36.7 $\mu \mathrm{m}) ; \mathrm{E}=28.9 \mu \mathrm{m}(27.1-30.7 \mu \mathrm{m})$; $\mathrm{P} / \mathrm{E}=1.2$.

- Schizolobium parahyba (Vell.) Blake. (Fabaceae-Mimosoideae). Pollen grains are monads, isopolar, radiosymmetrical, small to medium size, ambit circular, and 3 -colporate, with a microreticulate surface and an exine $1.1 \mu \mathrm{m}$ thick.

- Schinus terebinthifolius L. (Anacardiaceae). Pollen grains are monads, isopolar, radiosymmetrical, small to medium size, ambit subcircular, 3-colporate, and longicolpate, with a striate-reticulate surface and an exine $1.4 \mu \mathrm{m}$ thick.

- Solanum aculeatissimum Jacq. (Solanaceae). Pollen grains are monads, isopolar, small size, radiosymmetrical, prolate spheroidal, ambit rounded, 3-colporate, and endoapertures lalongates, with a psilate surface and an exine $1.6 \mu \mathrm{m}$ thick. Measurements: $\mathrm{P}=23 \mu \mathrm{m}(21.9-24.1 \mu \mathrm{m})$; $\mathrm{E}=22.6 \mu \mathrm{m}(21.1-24.1 \mu \mathrm{m}) ; \mathrm{P} / \mathrm{E}=1.02$.

- Solanum asperolanatum Ruiz \& Pav. (Solanaceae). Pollen grains are monads, isopolar, radiosymmetrical, small size, prolate spheroidal, ambit subtriangular to rounded, and 3-colporate, with a psilate surface and an exine $1.3 \mu \mathrm{m}$ thick. Measurements: $\mathrm{P}=21.2 \mu \mathrm{m}(19.6-22.8 \mu \mathrm{m})$; $\mathrm{E}=19.3 \mu \mathrm{m}(18.1-20.5 \mu \mathrm{m}) ; \mathrm{P} / \mathrm{E}=1.1$.

- Tapirira guianensis Aubl. (Anacardiaceae). Pollen grains are monads, isopolar, radiosymmetrical, small size, prolate spheroidal, ambit subcircular to circular, 3-colporate, longicolpate, and endoapertures lalongates, with a striate surface and an exine $1.5 \mu \mathrm{m}$ thick.

- Wedelia paludosa DC. (Asteraceae). Pollen grains are monads, isopolar, radiosymmetrical, small size, ambit rounded, 3-colporate, and a surface with spines $3.9 \mu \mathrm{m}$ high and an exine $1.0 \mu \mathrm{m}$ thick.

\section{DISCUSSION}

The dense Atlantic Rainforest made the collection and identification the majority of plants foraged by $T$. angustula quite difficult.
Some authors showed that Asteraceae and Fabaceae were the favorite plant families of $T$. angustula. Studies conducted in Riparian Forest in Southern Brazil (Garcia et al. 2008) identified 10 plant species visited by $T$. angustula belonging to six families: Asteraceae (three), Fabaceae (two), Myrtaceae (two), Rutaceae (two) and Euphorbiaceae (one).

In other surveys conducted in Atlantic Rain Forest, Knoll (1985) observed 66 plants visited by $T$. angustula, among them, only three species were presented in our study: Mangifera indica, Schinus terebinthifolius and Wedelia paludosa. Fukusima-Hein et al. (1986) cited 60 plants, among them only two are common in our study: Schinus terebinthifolius and Schizolobium parahyba. Ramalho (2004) cited six plants, none found in our study: Dendropanax cuneatum Decne. \& Planch. (Araliaceae), Baccharis anomala DC. (Asteraceae), Protium widgrenii Engl. (Burseraceae), Clethra scabra Pers. (Clethraceae), Sapium glandulatum (Vell.) Pax (Euphorbiaceae), Ocotea puberula (Rich.) Nees (Lauraceae).

Other plants were also listed by Knoll (1985) and Fukusima-Hein et al. (1986): Aster laevis (Asteraceae), Muntingia calabura (Elaeocarpaceae) and Salvia splendens (Lamiaceae) (Knoll 1985); Agave sisalana (Agavaceae), Coleus blumei (Labiatae), Erythrina speciosa (Fabaceae) and Lagerstroemia indica (Lythraceae) (Fukusima-Hein et al. 1986). However, these authors did not report the frequency of the visitors in the related plants.

In a survey conducted in the same region, Morgado et al. (2011) reported as more frequently visited plant families, Melastomataceae, Myrtaceae, Piperaceae, Caesalpiniaceae, Meliaceae, Cyperaceae and Cecropiaceae, suggesting a general behavior of $T$. angustula. Field observation of the T. angustula' behavior, their plant resources and the pollen morphologies of these plants, suggests that the trophic niche of T. angustula in the Atlantic Rainforest is wide. However, the variation of the distribution of this particular bee and its related flora in the study sites also indicated that removal of the native vegetation can affect bee populations 
through the loss and changes in floral resources and nesting sites, as emphasized by Kremen et al. (2004). Currently, the regions fringing on the Atlantic Rainforest are used intensively by livestock production, which represents a serious threat to T. angustula and other stingless bee species survival.

Nowadays the conservation of forests is an important issue in Brazil and is based on projects of sustainable use and management of stingless bees. For this, the availability of resources and nesting sites, the logging activity and forest composition are important concerns.

Finally, to support the rational use of stingless bees, it is necessary to know the plant species that act as resources to the bees in their natural environment. Direct observation in the field and Palinology, both contribute to enhance the list of $T$. angustula plants. There are strong differences between pollen types, especially regarding the pollen grains' shape. The diet of $T$. angustula is so ample that this study suggests that the variety of plant species have a high value as trophic resources for this bee species in the Atlantic Rainforest.

\section{ACKNOWLEDGMENTS}

This study was supported by FAPERJ. We are grateful to Fundação Instituto Estadual do Meio Ambiente (INEA) for allowing part of this work. Special thanks to local beekeepers and to Leila Morgado for valuable contributing in the field.

\section{RESUMEN}

Para apoyar el uso racional de las abejas sin aguijón, es necesario conocer las especies de plantas que actúan como fuentes de recursos para estas abejas en su ambiente natural. El objetivo de este estudio fue identificar las especies de plantas que fueron visitadas con mayor frecuencia por abejas Tetragonisca angustula y describir los granos de polen de estas plantas. El estudio se realizó en la Mata Atlántica, donde se recogieron las abejas, las plantas con flores y el polen de las cargas corbiculares de las abejas obreras. La observación de campo mostró la presencia de plantas pertenecientes a diez familias y las cargas de polen mostraron la presencia de tipos de polen pertenecientes a 26 familias botánicas. Hubo grandes diferencias entre los tipos de polen, sobre todo teniendo en cuenta la ornamentación de los granos de polen. Este estudio sugiere un alto valor de estas especies de plantas como recursos tróficos para las abejas jataí en el sub-bosque de la Mata Atlántica. Las alteraciones de los fragmentos de bosque pueden afectar la disponibilidad de recursos para Tetragonisca angustula y otras abejas sin aguijón y ser un gran obstáculo para la su crianza sostenible.

Palabras clave: abejas sin aguijón, morfología del polen, nicho trófico, Meliponina, bosque tropical.

\section{REFERENCES}

Ab'Sáber, A.N. 1977. Os domínios morfológicos na América do Sul. Geomorfologia 52: 1-21.

Barth, O.M. 1989. O pólen no mel brasileiro. Luxor, Rio de Janeiro, Brasil.

Barth, O.M. \& T.S. Melhem. 1988. Glossário ilustrado de palinologia. UNICAMP, Campinas, São Paulo, Brasil.

Erdtman, G. 1960. The acetolysis method: a revised description. Sv. Bot. Tidskr. Lund. 54: 561-564.

Fukusima-Hein, Y.K., M. Cortopassi-Laurino, V.L. Imperatriz-Fonseca \& A. Kleinert-Giovanini. 1986. Como conhecer plantas apícolas. Api. Bras. 1: 34-38.

Fundação SOS Mata Atlântica \& Instituto Nacional de Pesquisas Espaciais (INPE). 2009. Atlas dos remanescentes florestais da Mata Atlântica: período 2005 2008. Relatório Final. INPE, São José dos Campos, São Paulo, Brasil.

Garcia, R.C., M. Curti, T.R. Lohmann, B.G. Pires, S.C. Camargo, A.L. Britzke, V.M. Fulber \& M.R.F. Machado. 2008. Flora apícola em fragmentos de Mata Ciliar no município de Marechal Cândido Rondon (BR). Rev. Sci. Agr. Par. 7: 91-100.

Kerr, W.E., G.A. Carvalho, A.C. Silva \& M.G.P. Assis. 2001. Aspectos pouco mencionados sobre a biodiversidade da Amazônia. Parc. Est. 12: 20-41.

Knoll, F.R.N. Abundância relativa das abelhas no Campus

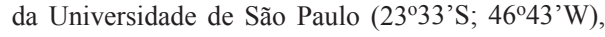
com especial referência à Tetragonisca angustula Latreille. 1985. São Paulo, USP, 78p. Dissertação (Mestrado) Departamento de Zoologia (also available online: http://eco.ib.usp.br/beelab/calendario_jatai. htm).

Kleinert, A.M.P. \& V.L.I. Fonseca. 1995. Utilização de recursos florais por abelhas sem ferrão em diferentes ecossistemas. Laboratório de Abelhas, Departamento de Ecologia, IB, USP (Downloaded: january 28, 2009, http://www.webbee.org.br/beeplant).

Kremen, C., N.M. Williams, R.L. Bugg, J.P. Fay \& R.W. Thorp. 2004. The area requirements of an ecosystem 
service: crop pollination by native bee communities in California. Ecol. Let. 7: 1109-1119.

Lorenzon, M.C.A., M.M.S. Conde \& C.G. Barbosa. 2006. Eusocial Apidae in Tropical Insular Region. Bra. Arc. Bio. Tec. 49: 733-738.

Louveaux, J., A. Maurizio \& G. Vorwohl. 1970. Methods of Melissopalynology. B. Wor. 59: 139-157.

Malagodi-Braga, K.S. \& A.M.P. Kleinert. 2004. Could Tetragonisca angustula Latreille (Apinae, Meliponini) be used as strawberry pollinator in greenhouses? Aust. J. Agric. Res. 55: 771-773.
Morgado, L.N., R.C. Andrade, M.C.A. Lorenzon \& V.G. Esteves. 2011. Padrão polínico utilizado por Tetragonisca angustula Latreille (Apidae: Meliponina). Acta Bot. Bras. 25: 932-934.

Ramalho, M. 2004. Stingless bees and mass flowering trees in the canopy of Atlantic Forest: a tight relationship. Acta Bot. Bras. 18: 37-47.

The Angiosperm Phylogeny Group. 2003. An update of the Angiosperm Phylogeny Group classification for the orders and families of flowering plants: APG II. Bot. J. Lin. Soc. 141: 399-436. 
